\title{
IMPLEMENTATION OF GOOD CORPORATE GOVERNANCE (GCG) AND PROFIT-SHARING FINANCING ON PROFITABILITY IN SHARIA COMMERCIAL BANKS
}

\author{
Sri Lestari Kurniawati ${ }^{1}$, Zubaidah Nasution ${ }^{2}$ \\ Universitas Perbanas Hayam Wuruk Surabaya \\ lestari@perbanas.ac.id', zubaidah@perbanas.ac.id ${ }^{2}$ \\ DOI : (If your article has been accepted and published)
}

\begin{abstract}
This study aims to determine the effect of Good Corporate Governance and profit-sharing financing on the performance of sharia commercial banks in Indonesia as measured by profitability.

This study is quantitative by using Profitability variables (ROA and ROE) as the dependent variable and Good Corporate Governance and profit-sharing financing (mudharabah, musyarakah) as independent variables. The purposive sampling was used as the sampling method in order to obtain 10 Sharia Commercial Banks (SCB) with a study period of 2009-2018. The analysis technique used is descriptive analysis and statistical analysis of panel data with eviews 8.0.

The results of the study stated that Good Corporate Governance and mudhorobah profit-sharing had a significant positive effect on profitability (ROA and $\mathrm{ROE}$ ).
\end{abstract}

Keywords: Good Corporate Governance, $\mathrm{ROA}, \mathrm{ROE}$

\section{Introduction}

The existence of banking in Indonesia has a great impact both for the community and for large, medium and small industries. Since the bank is a place to strengthen capital as well as a place to store funds owned by the public that may provide a sense of security and comfort. Therefore, the existence of sharia banks is a solution that may increase public confidence in banking activities in Indonesia. (Pudail. M, 2018). Sharia bank is one of the banking products based on the Islamic or sharia economic system that is developing in Indonesia (Marimin Agus, 2015).

The annual development of Islamic banks has increased, both Sharia Commercial Banks (SCB) and Sharia Business Units (SBU). The increasing number of SCB and SBU cannot be separated from the achievement of Islamic bank performance through profitability. Profitability is an indicator to measure the corporate's ability to generate profits either through the achievement of return on assets (Rizky, 2018) and return on equity (Desiana L, 2016)). The profitability growth (ROA and ROE) of sharia banks can be shown in the following figure: 
Figure 1

The Profitability Growth (ROA and ROE) of Sharia Banks in Indonesia On Year 2015 -2019

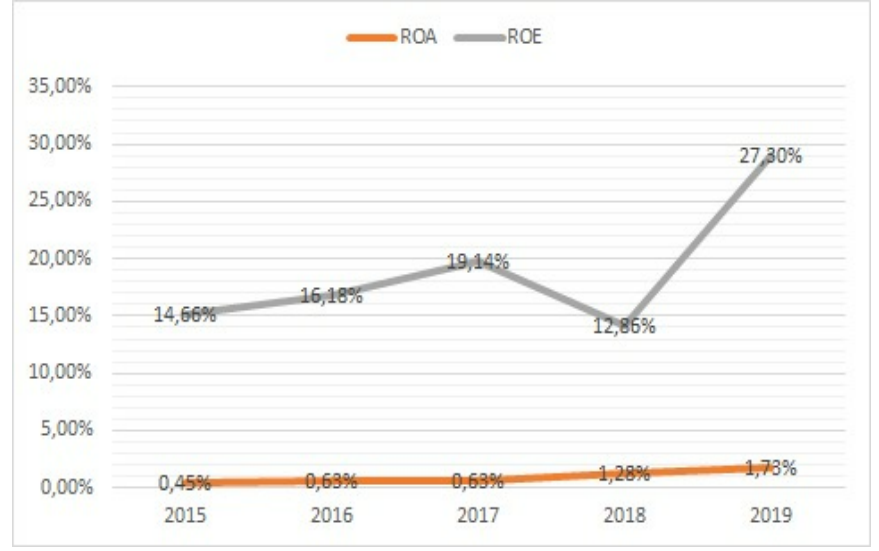

Source: Sharia Banking Statistic, 2019

Figure 1 above shows profitability growth (ROA) for 5 years commencing from 2015 at $0.49 \%$ and increasing every year until 2019 by $1.73 \%$. Likewise, ROE which in 2015 was $14.66 \%$ increased every year until 2019 by $27.30 \%$ except in 2018 there was a decrease of $6.28 \%$ from 2017 . Such an illustration indicates that the profitability of sharia commercial banks for 5 years has performed well. The increased performance of sharia banks through the achievement of profitability is inseparable from the implementation of good corporate governance (GCG) in sharia banks.

GCG is a system that regulates, manages and oversees the business control process to increase the corporate's profitability as well as a form of attention to primary and secondary stakeholders. (Pratiwi Angrum, 2016). According to Law no. 21 of 2008 article 34 concerning Sharia Banking (Sharia Banking Law), sharia banks are required to implement GCG. In addition, Bank Indonesia has issued PBI No. 11/33/PBI/2009 on 9th December 2009 concerning the implementation of GCG for SCB and SBU which was implemented in 2010. The implementation of good governance is a determining factor for the health of sharia banks (Ihsan, 2016). Good corporate governance is related to the hadith of the Prophet Muhammad narrated by Aisyah r.a. which means "Indeed, Allah likes it when someone does a job well done." The better and stronger the governance mechanism, the bank's performance will greatly increase (Priyono Sugeng, 2019).

The results of study by Sanjai Bhagat and Bolton (2008) prove that good corporate governance has a positive effect on operating performances as proxied by return on assets. However, according to the results of Eksandy Arry's study (2018), it proves that GCG has no significant effect on return on assets (ROA) and according to the study results of Pudail M. (2018) also prove that GCG has no effect on ROE.

In addition to corporate governance (GCG), another factor that affects bank profits is the financing disbursed by the bank to its customers. (Rahayu Y.S, 2016). Financing is 
funds given by one party to another that supports the planned investment (Rivai, 2010: 681). In accordance with sharia banking statistics found in the Financial Services Authority (OJK), it was recorded that in February 2017, financing based on sharia principles reached IDR 289.99 trillion. There are 4 types of contracts or principles of sharia banks in distributing their financing, they are the principle of buying and selling, profit sharing, the principle of lease and complementary contracts, as for the dominating financing in sharia banks, one of which is the principle of profit sharing. (Rahman \& Rochmanika, 2012). The better Islamic banks distribute financing for the results then the sharia banks income may increase (Rahayu Y.S, 2016).

The results of several studies prove that mudharabah profit-sharing financing has no effect on profitability, musyarakah profit-sharing financing has a negative effect on profitability in Islamic Commercial Banks (Putra Purnama, 2018). Rahayu Y.S. (2016) proves that mudharabah profit-sharing financing has a significant positive effect on profitability, musyarakah profit-sharing financing has a significant negative effect on profitability. Amalia (2016) also proves that mudharabah profit-sharing has an effect on profitability. As well as, the results of Faradila's study (2017) prove that musharaka profitsharing has a positive effect on the profitability of Sharia Commercial Banks.

Some of the studies above were used as the basis for this study to create a study gap: first, the GCG measurement method used by Sanjai, it is: board independence, stock ownership of board members and Sanjai's study was conducted in America. In Eksandy's study, the GCG measurement method used is: the board of directors, independent commissioners, DPS and the audit committee, while in this study the GCG measurement method used is self-assessment. In research on profit-sharing financing, there are several differences related to the number of samples used in Putra and Rahayu's research as many as 4 SCB, in Amalia's study, there were 2 SCB and the sample for Faradila's study was 11 $\mathrm{SCB}$, so the study results from profit-sharing financing proved different results. This study used a sample of 10 Islamic Commercial Banks (SCB), with the difference in the number of samples and the study results on profit- sharing financing which also gave different results, that is why this research was carried out again.

Based on the description above, the aims of this study are: to analyze the implementation of Good Corporate Governance (GCG), profit sharing financing on the profitability of sharia commercial banks in Indonesia.

\section{Review of Related Literature Agency Theory}

Agency theory developed by Michael Johnson. Good Corporate Governance (GCG) in Sharia Banking sees the corporate's management as "agents" for shareholders, will act with full awareness for its own interests, not as a wise and prudent and fair party to shareholders (Romdhoni, 2015). It provides awareness that there is an agency relationship 
that occurs when one or more individuals are referred to as principals who hire other individuals or organizations, which may also be referred to as agents, to perform a number of services and delegate decision-making authority to the agent.

\section{Good Corporate Governance}

Corporate Governance has a meaning as an internal control system in a corporate that aims to manage significant risks so as to secure corporate assets and increase shareholder investment value in the long term. (Budiman Fathan, 2016). Good corporate governance is defined by the World Bank (World Wide) as rules, a collection of laws and rules that must be met to improve the performance of the company's resources and function in generating long-term sustainable economic value for shareholders or the environment as a whole. (Effendi, 2016). Corporate Governance is an expected concept which may function to provide trust to shareholders that the management is able to work well so that it may fulfil the interests of shareholders and the public interest. (Eksandy Arry, 2018). Good Corporate Governance is measured by using a self-assessment composite value. GCG assessment is an assessment of the principles of GCG with a predetermined absolute value called the composite value. (Desiana L, 2016).

\section{Table 1}

\section{Self-Assessment Composite Value}

\begin{tabular}{|l|l|}
\hline \multicolumn{1}{|c|}{ Composite Value } & \multicolumn{1}{|c|}{ Composite Predicate } \\
\hline Composite Value $<1.5$ & Very Good \\
\hline $1.5 \leq$ Composite Value $<2.5$ & Good \\
\hline $2.5 \leq$ Composite Value $<3.5$ & Fair \\
\hline $3.5 \leq$ Composite Value $<4.5$ & Poor \\
\hline $4.5 \leq$ Composite Value $\leq 5$ & Bad \\
\hline
\end{tabular}

Source: Circular Letter No. 12/13/Dpbs/PBI/2010

\section{Profit Sharing Financing}

According to Bank Indonesia statistics, profit-sharing financing is one of the financing patterns that dominates sharia banks. Profit sharing financing is a financing distributed to customers who need funds in the form of a cooperation agreement between the bank and the customer. In sharia banking, profit-sharing financing can be carried out in 4 contracts, but the most widely used are mudharabah and musyarokah contracts. (Rahman \& Rochmanika, 2012).

Mudharabah financing is a partnership between a partner who gives money to another partner to invest in a commercial corporate. Shahibul maal (the bank) is obliged to provide $100 \%$ of funds to mudharib (customers) and customer only manages businesses that have been determined by the bank (Rivai, 2012: 299). Mudharabah business profits are 
divided according to the agreement in the contract, if the loss is borne by the owner of the capital as long as the loss is not due to the negligence of the manager, but if the loss is due to negligence or fraud by the manager, the manager shall be responsible for the loss (Antonio, 2011: 56).

Musyarakah financing is a financing carried out by the bank, where the bank acts as the owner of the funds or participates as a business partner managed by another party. The profit earned is in accordance with the amount of capital invested and it has been agreed at the beginning of the agreement, if the business fails, the losses will be shared in accordance with the proportion of participation (Rivai, 2010: 193).

\section{Corporate Profitability}

According to Suwiknyo (2010) profitability is a ratio that shows the level of bank effectiveness that may be achieved through its operational efforts. Similarly, the Indonesian Bankers Association (2018) also states that profitability or profitability is the ability of banks to earn profits during a certain period. Profitability ratio is proxied by ROA and ROE. ROA is used to measure the bank's ability to generate profits through the management of total assets owned by the bank and ROE is used to measure the bank's performance in managing its own capital to get a net profit. (Setyawati Agus, 2016). The higher this ratio means the profit earned by the bank is also greater (Desiana L, 2016).

\section{Study Method}

\section{Type of Study}

This study is a quantitative research that is explanative since the study wants to explain the relationship and relationship between the variables studied, the independent variable and the dependent variable. Based on the data, this study is included in study with panel data in the form of financial report data from SCB (Sharia Commercial Banks) in Indonesia for the period 2009 - 2018. The data used are the financial statements of corporates listed on the website of Bank Indonesia (www.bi.go.id) and ojk.go.id. When viewed from the source of the data, this study is a secondary study because it uses secondary data. If viewed based on the purpose of this study, including causality study which aims to identify the influence between variables.

\section{Population and Sample}

The population of this study is all Sharia Commercial Banks in Indonesia as many as 14 Banks. The sampling technique was carried out by purposive sampling in order to obtain a representative sample in accordance with the selected sample criteria. The criteria used are as follows: 1) Sharia Commercial Banks (SCB) listed in the Indonesian Banking Directory in 2009 - 2018. 2) Sharia Commercial Banks (SCB) which is still operating until 2018. 3) Sharia Commercial Banks (SCB) which publishes annual reports from 2009-2018. 4) Sharia Commercial Banks (SCB) which publishes GCG reports from 2009-2018. 
Based on the sample criteria, there are 10 Sharia Commercial Banks (SCB) which meet the requirements.

\section{Variable Measurement}

The variables in this study consisted of the dependent variable, it is profitability and the independent variable consisted of GCG and profit-sharing financing (mudharabah and musyarokah).

Table 2

Variable Measurement

\begin{tabular}{|l|l|}
\hline \multicolumn{1}{|c|}{ Variable } & \multicolumn{1}{c|}{ Measurement } \\
\hline Profitability (ROA) & $R O A=\frac{\text { Net profit after tax }}{\text { Average Total Assets }} \times 100 \%$. \\
\hline Profitability (ROE) & $R O E=\frac{\text { Net profit after tax }}{\text { Average Total Capital } \text { (Equity) }} \times 100 \%$ \\
\hline Good Corporate Governance & Self-Assessment composite value \\
\hline Mudharabah Financing & $\begin{array}{l}\text { Amount of Mudharabah financing provided by Sharia } \\
\text { Commercial Banks (SCB) }\end{array}$ \\
\hline Musyarokah Financing & $\begin{array}{l}\text { Amount of Musyarokah financing provided by Sharia } \\
\text { Commercial Banks (SCB) }\end{array}$ \\
\hline
\end{tabular}

\section{Data Analysis}

The data analysis used were descriptive analysis techniques and statistical analysis. Descriptive analysis is used to describe descriptively data from research variables. The results of the descriptive analysis may provide a general description of the sample used in the study, besides that the results of the descriptive analysis may also be used as a reinforcement of arguments in hypothesis testing. The next analysis is statistical analysis using panel data regression with Eviews 8.0 application. The use of panel data regression in this study is due to the combination of time series data and cross-sectional data.

\section{Results and Discussion}

\section{Descriptive Analysis Results}

This analysis describes descriptively the profitability variables which are proxied by return on assets and return on equity, mudhorobah financing, musyarokah financing and Good Corporate Governance which explained as follows:

Table 3

Descriptive Analysis

\begin{tabular}{|l|c|c|c|c|}
\hline & Min. & Maks. & Mean & Std. Dev. \\
\hline Profitability (ROA) & -10.77 & 3.29 & 0.52 & 1.81 \\
\hline Profitability (ROE) & -94.01 & 32.87 & 3.28 & 16.86 \\
\hline Mudhorobah Financing & 7.24 & 26.72 & 17.40 & 5.55 \\
\hline Musyarokah Financing & 9.66 & 28.55 & 18.83 & 6.07 \\
\hline
\end{tabular}




\begin{tabular}{|l|l|l|l|l|}
\hline Governance (GCG) & 4.00 & 7.00 & 5.30 & 0.52 \\
\hline
\end{tabular}

\section{Source: study data, processed data}

Based on table 3, it can be explained that the minimum ROA variable value of 10.77\% was owned by PT Bank Panin Dubai Syariah in 2017, it shows the bank's inability to manage its assets to increase revenue or reduce operating costs. The maximum value for the ROA variable of 3.29\% was owned by Panin Dubai Syariah Bank in 2012, meaning that in 2012 Panin Dubai Syariah Bank was able to manage its assets well so that its income increased. Judging from the average return on assets (ROA) of Islamic commercial banks of $0.52 \%<$ of the standard deviation value of $1.81 \%$, it means that the data variation is relatively high and heterogeneous.

The minimum ROE variable value of $-94.01 \%$ is owned by PT Bank Panin Dubai Syariah in 2017 , it shows the bank's inability to manage its equity to increase revenue. The maximum value for the ROE variable of $32.87 \%$ is owned by PT Bank Muamalat Indonesia Tbk. in 2013, meaning that in 2013 PT Bank Muamalat was able to manage its equity well so that its income increased. Judging from the average return on equity (ROE) of Islamic commercial banks of $3.28 \%<$ from the standard deviation of $16.86 \%$, it means that the variation in the data is relatively high and heterogeneous.

Next is the minimum value for mudhorobah financing of $7.24 \%$ owned by PT Bank Mega Syariah in 2015, which means that the mudhorobah financing provided by PT Bank Mega Syariah is the lowest compared to other Islamic banks in 2015, while the maximum value of mudhorobah financing is $26.72 \%$ owned by PT Bank Syariah Bukopin in 2015, which means that PT Bank Syariah Bukopin in issuing mudhorobah financing was high in 2015 compared to other Islamic banks in the same year. In addition, it also shows an average value of $17.40 \%>$ of the standard deviation of $5.55 \%$, meaning that the variation of the data is relatively low and homogeneous.

Musyarokah financing with a minimum value of 9.66\% was owned by PT Mega Syariah in 2014, meaning that the musyarokah financing provided by PT Bank Mega Syariah was the lowest compared to other Islamic banks in 2014, for a maximum value of $28.55 \%$ owned by PT Syariah Bukopin in 2017 and 2018 which means that the musyarokah financing provided by PT Syariah Bukopin is the lowest compared to other Islamic banks in 2017 and 2018. The average value (mean) for musyarokah financing is $18.83 \%>$ of the standard value the deviation is $6.07 \%$, meaning that the variation of the data is relatively low and homogeneous.

Governance (GCG) which is measured by using a self-assessment composite value, where the minimum value for GCG of 4.00 is owned by PT Bank Victoria Syariah in 2015 and PT Bank Muamalat Indonesia 2018, which means that a low composite value indicates a GCG implementation mechanism has not effective in Islamic commercial banks. The maximum value of 7.00 is owned by PT Bank Jabar Banten Syariah from 2010 to 2012, 
meaning that a high composite value indicates an effective GCG implementation mechanism in Islamic commercial banks. The average value (mean) for GCG is $5.30 \%>$ of the standard deviation value of $0.52 \%$, meaning that the variation in the data is relatively low and homogeneous.

\section{Statistical Analysis Results}

Statistical analysis used in this study is panel data regression carried out through panel data model testing to determine the right model.

\section{Model Testing}

Table 4

Testing panel data regression models

\begin{tabular}{|c|c|c|c|}
\hline \multicolumn{4}{|c|}{ Model 1 (Preferability/ROA) } \\
\hline Method & Testing & Result & Conclusion \\
\hline Chow Test & Common Effect vs Fixed Effect & Common Effect & \multirow{2}{*}{$\begin{array}{l}\text { Common } \\
\text { Effect }\end{array}$} \\
\hline $\begin{array}{l}\text { Lagrange } \\
\text { multiplier Test }\end{array}$ & Common Effect vs Random Effect & Common Effect & \\
\hline \multicolumn{4}{|c|}{ Model 2 (Profitability/ROE) } \\
\hline Method & Testing & Result & Conclusion \\
\hline Chow Test & Common Effect vs Fixed Effect & Fixed Effect & \multirow[t]{2}{*}{ Random Effect } \\
\hline Hausman Test & Fixed Effect vs Random Effect & Random Effect & \\
\hline $\begin{array}{l}\text { Lagrange } \\
\text { multiplier Test }\end{array}$ & \multicolumn{2}{|c|}{$\begin{array}{l}\text { The results of the Lagrange Multiplier test showed the probability } \\
\text { of } 0.0105<\text { of } \alpha 5 \% \text {, meaning the model selected through the } \\
\text { testing of the Lagrange Multiplier is Random Effect. }\end{array}$} & Random Effect \\
\hline
\end{tabular}

Source: research data, processed data

Based on the results of testing the panel data regression model in Table 4 it can be concluded that for the selected model 1 (Profitability / ROA) the model is common effect while the model 2 (profitability / ROE) because the selected is Random Effect, the test is continued, namely the Lagrange Test Multiplier and The conclusion of the selected model is Random Effect.

\section{Common Effect Model Analysis (ROA)}

After the election test of estimation model for the profitability variable measured by ROA, the selected Common Effect model which results can be seen in Table 5 as follows:

Table 5.

Results of Model 1 Common Effect Analysis (ROA)

\begin{tabular}{|l|l|l|l|l|}
\hline \multicolumn{1}{|c|}{ Variable } & \multicolumn{1}{c|}{ Koef.Beta } & \multicolumn{1}{c|}{ t statistic } & \multicolumn{1}{c|}{ Prob. } & \multicolumn{1}{c|}{ Conclusion } \\
\hline C & -5.492281 & -2.83857 & 0.0058 & \\
\hline Mudhorobah & 0.241612 & 2.022138 & 0.0467 & Significantly positive \\
\hline Musyarokah & -0.257724 & -2.37867 & 0.0199 & Significant negative \\
\hline GCG & 1.257746 & 3.370017 & 0.0012 & Significantly positive \\
\hline R Squared & & 0.194218 \\
\hline Adjusted R-squared & 0.161987 \\
\hline
\end{tabular}




\begin{tabular}{|l|l|}
\hline F count & 6.02576 \\
\hline Probabilities & 0.000984 \\
\hline
\end{tabular}

Source: data research, processed data

\section{Partial Regression Test Results}

Based on Table 5 Testing of the Common Effect Model T Model, shows the result that the value of the Mudhorobah financing variable statistics is 2.022138 with a probability of $0.0467<$ from $\alpha 5 \%$, which means that mudhorobah financing has a significant positive effect on profitability (ROA). The next $\mathrm{T}$ value of the Musyarokah financing variable statistics is -2.37867 with a probability of $0.0199<$ of $\alpha 5 \%$ which means that the financing of Musyarokah has a significant negative influence on profitability (ROA). The results of the GCG (Governance) variable test show a statistical t value of 3.370017 with a probability of $0.0012<$ from $\propto 5 \%$ which means that GCG (Governance) has a significant positive effect on profitability (ROA).

\section{Model Existence Test Results (F test)}

The statistical test results indicate that the statistics $f$ value of 6.02576 with a significant level of $0,000934<$ of a $5 \% \alpha$ value indicating that the model is fit to use.

\section{Determination Coefficient Test Results (R2)}

Based on table 5 obtained R-squared value of 0.194218 which means that $19.42 \%$ of variations of the Profitability variable (ROA) can be explained by the Mudhorobah Financing variable, financing Musyarokah and GCG (Governance) while the remaining $80.58 \%$ is influenced by variations in other variables outside the model.

\section{Discussion}

\section{The Effect of Mudhorobah Financing on Profitability (ROA).}

The results of the study prove that mudhorobah financing has a significant positive influence on profitability (ROA), which means that the higher the financing of mudharobah it will result in the higher profit. The convenience of profit sharing systems and requirements to obtain mudhorobah financing will affect the interest of customers in developing their business both a small business and medium-sized business at Islamic banks so that high income from Mudhorobah financing will increase the net profit of Islamic banks. Sharing funding financing is one component of the compiler of assets for Islamic banking, Islamic banks obtain income from profit sharing in accordance with the agreed upon ratio with customers. (Muhammad, 2005).

The results of this study are in accordance with the results of Amalia (2016) research which states that the higher the financing of Mudhorobah is channeled, the higher the benefits obtained by Islamic commercial banks that are proxied by return on assets.

\section{The influence of Musyarokah Financing on Profitability (ROA).}


The results of the study prove that the Musyarokah financing has a significant negative influence on profitability (ROA), which means that the higher the Musyarokah financing, it will produce a low profit. Sharing Financing With Akad Musyarakah is in great demand by customers after Mudharabah, the high interest caused a lot of funds channeled through Musyarokah financing but it was not balanced with good management. This can be shown that in 2017 the value of problem loans at Islamic banks experienced a significant increase (Okefinance, 2017) so that the condition was very influential on the achievement of Islamic bank's profits.

The results of this study are the same as the results of research from Faradila Cut (2017) which stated that Musyarokah financing has a significant negative influence on the profitability (ROA) of Islamic Commercial Banks,

\section{GCG Influence on Profitability (ROA)}

The application of good GCG (governance) will make investors respond positively to the company's performance, especially Islamic commercial banks (BUS). The results of this study proved that GCG (Governance) had a significant positive influence on profitability (ROA), meaning that the more effective GCG would increase the benefits of Islamic commercial banks. Good GCG practices will encourage sharia commercial banks to visit sharia values that are included in the Sharia Principle so that it can be used to maintain Islamic financial management professionally.

The results of this study are in accordance with the results of research from Nuswandari (2009) which prove that the essence of GCG is economically will maintain business continuity, both profitability and growth, managers will make financial decisions that can benefit all parties. The results of Noor Dwi Y. (2016) also stated that the GCG carried out in accordance with the guidelines would have a positive effect on the achievement of the benefits of sharia commercial banks.

\section{Random Effect Model Analysis (ROE)}

The next elected estimation model for the profitability variable measured by ROE is the Random Effect Model whose results can be seen in Table 6 as follows:

\section{Table 6}

\section{Results of Model 2 Random Effect Analysis (ROE)}

\begin{tabular}{|l|l|l|l|l|}
\hline Variable & Beta Coefficient & t statistic & Prob. & Conclusion \\
\hline C & -62.21233 & -3.56174 & 0.0006 & \\
\hline Mudhorobah & 2.310898 & .985043 & 0.0508 & Significantly positive \\
\hline Musyarokah & -2.281308 & -2.14189 & 0.0354 & Significantly negative \\
\hline GCG & 12.77704 & 3.69608 & 0.0004 & Significantly positive \\
\hline R Squared & & 0.204831 \\
\hline Adjusted R-squared & 0.173025 \\
\hline F count & 6.439869 \\
\hline Probability & 0.000613 \\
\hline
\end{tabular}




\section{Partial Regression Test Results}

Based on table 6 , it shows the value of the statistics for the mudhorobah financing variable of 1.985043 with a probability of $0.0508<$ from $\alpha 10 \%$ which means that mudhorobah financing has a significant positive influence on profitability (ROE). Next is the value of the statistics variable financing variables as much as -2.14189 with a probability of $0.0354<$ of $\alpha 5 \%$ which means that the financing of Musyarokah has a significant negative influence on profitability (ROE). The results of the GCG (Governance) variable test show a statistical $t$ value of 3.69608 with a probability of $0.0004<$ of $\alpha 5 \%$ which means that GCG (Governance) has a significant positive effect on the profitability (ROE).

\section{Model Existence Test Results (F test)}

The statistical test results in Table 6 show that the statistics f value of 6.439869 with a significant level of $0.000613<$ of a value of $\alpha 5 \%$ indicate that the model is fit to use.

\section{Determination Coefficient Test Results (R2)}

The coefficient of determination (R2) aims to measure how far the model's ability explains the variation of the Profitability (ROE) variables. Based on table 10 obtained a Rsquared value of 0.204831 which means that $20.48 \%$ of variations of the Profitability (ROE) variables can be explained by the Mudhorobah Financing variable, Musyarokah financing and GCG (Governance) while the remaining $79.52 \%$ is influenced by variable variations others outside the model.

\section{Discussion}

\section{The Effect of Mudhorobah Financing on Profitability (ROE).}

The results of the study prove that mudhorobah financing has a significant positive influence on profitability (ROE), which means that the higher the financing of Mudhorobah, the profits of Islamic commercial banks (BUS) as measured by return on EQUTY (ROE) are increasing. The greater the financing channeled, the higher the benefits obtained by Islamic banks, so that it can help in returning capital and gaining profits. (Rahayu et al., 2016). The Mudhorobah Financing Akad is included in the Tijarah contract used in transactions that are profit and in accordance with the concept of profitability that one that influences profitability is financing distributed by the Bank so that if the financing is high, the profitability will also increase as a performance indicator of Islamic bank performance.

The results of this study are the same as the results of research from Rahayu et al (2016) that the mudhorobah profit sharing financing has a significant positive effect on profitability (ROE).

\section{The Influence of Musyarokah financing on Profitability (ROE).}

The results of the study stated that Musyarokah financing had a significant negative influence on profitability (ROE), meaning that the higher the Musyarokah financing, the 
profits of Islamic commercial banks (BUS) measured by return on EQUTY (ROE) will decrease. Basically, financing with profit sharing, namely Musyarakah, emphasizes the pattern of partnership relationship between the Bank and the customer so that this is in accordance with the properties of financing with akad musyarakah that has a high risk of the problem of uncertainty so that it will affect the acquisition of declining income.

The results of this study are the same as the results of the Putra P. (2018) study which stated that the Musyarokah financing had a significant negative effect on profitability. Rahayu et al (2016) also stated the same thing that the Musyarokah financing had a significant negative effect on profitability measured by (ROE). This indicates that the increase in the volume of financing with the artificial contract has an effect on the impairment of profits at Islamic commercial banks.

\section{GCG influence on Profitability (ROE).}

The results of the study stated that GCG (Governance) had a significant positive influence on profitability (ROE), which meant that the implementation of GCG (Governance) was getting better and experienced an increase, the benefits of Islamic commercial banks (BUS) were measured by return on EQUTY (ROE) more increasing. This shows that with the application of good GCG (governance) can reduce conflicts of interest that occurs so that it can foster the performance of Islamic banking in hopes of attracting investors to increase its investment.

The results of this study are in accordance with the results of research from Noor Dwi Yantiningsih (2016) and also Desiana L. (2016) which states that GCG has a significant positive influence on profitability measured by ROE.

\section{Conclusion}

This study aims to analyze the implementation of GCG (Governance) and Sharia Financing Contributions, namely Mudhorobah and Musyarokah on the profitability of sharia commercial banks measured by Return on Asset (ROA) and Return on Equity (ROE). Based on the results of the analysis, the following conclusions can be drawn: 1) Application of Good Corporate Governance and Mudhorobah Financing has a significant positive effect so that it can increase profitability (ROA and ROE) at Islamic banks in Indonesia. 2) Musyarakah financing has a significant negative effect on profitability (ROA and ROE) so that the purpose for this financing cannot be proven.

\section{Bibliography}

Antonio, Muhammad Syafi'i, a Sharia Bank of theory to Practice. Jakarta: Gema Insani Press, 2011.

Amalia, Nur. "Financing structure and influence of Bank Muamalat Indonesia and Bank Syariah MandiriPritability", Journal of Science and Risitancing, Vol. 5, No.5, 2016 
Budiman Fathan. "The influence of the quality of the application of Good Corporate Governance (GCG) on the level of return and risk of Islamic bank financing in Indonesia", Mustaqid Journal, Vol. 7 No. 2, December 2016

Desiana, L., Mawardi, \& Gustiana, S, "Influence of Good Corporate Governance of Profitability at Sharia Commercial Banks in Indonesia for the period 2010-2015", Finance, Vol. 2, No. 2, 2016.

Exandy Arry, "the influence of good corporate governance on financial performance in Islamic Syari'ah banking", Accounting Journal, Vol 5 No. 1, January 2018

Effendi, M. a, The Power of Good Corporate Governance: Theory and Implementation. " , Publisher Salemba Four, Edition 2, 2016

Faradilla, C., Arfan, M. \& Shabri, M. "The Effect of Murabahah's Financing of Istishna, Ijarah, Mudharabah, And musyarakah on the profitability of Islamic Commercial Banks in Indonesia", Master of Masters in Postgraduate University of Shia Kuala. Volume 6, Number 3, 2017

Ihsan, D. N. "The quality of the application of Good Corporate Governance at Islamic General Banks in Indonesia and its influence on financial performance", the Islamic economy, volume 7, number 2. 2016.

Marimin Agus, Abdul Haris Romdhoni and Tira Nur Fitria Marimin. "Sharia Bank Development in Indonesia", Islamic Economics Journal, Vol. 01, No. 02, July 2015 Muhammad. Sharia Bank Financing Management. Yogyakarta: upp ykpn. 2005.

Nurhayati, Sri and Wisalm, Sharia Accounting in Indonesia. Jakarta: Salemba four. 2011.

Nuswandari, Cahyani. "The influence of Corporate Governance Perception Index on company performance in companies listed on the Jakarta Stock Exchange", Business and Economic Journal, Vol. 16, No. 2, 2009.

Noor Dwi Yantiningsih. "The influence of the quality of the World Corporate Governance (GCG) (GCG) on Kinerjuangan in Indonesian Islamic banking (2010-2014 period)", Journal of Masters in Postgraduate Accounting for Shia Kuala University, Volume 5, No. 1, 2016.

Priyono Sugeng. "Concept and implementation of good corporate governance in Islamic banking in Indonesia", Journal of Economics and Islamic Business, Vol. 3 No. 2, October 2019.

Putra Purnama. "The influence of Yaan Yaan Mudharabah, Musyarakah, Murabahah, and Ijarah towards the profitability of 4 Islamic General Banks for the 2013-2016 period", Journal of Organization and Management, Volume 14, Number 2, 2018

Pudail. M. "Good Corporate Governance in Improving Islamic Bank Financial Performance", Wahana Islamika: Journal of Islamic Studies, Vol 4 No. 1, 2018

Pratiwi Angrum. "The effect of the quality of the application of Good Corporate Governance (GCG) on financial performance at Sharia Commercial Banks in 
Indonesia (2010-2015)", Al-Tijary Journal of Economics and Islamic Business, Vol. 2, No. 1, 2016.

Permata, R. I., Yaningwati, F., \& Z. A, Z. "Analysis of Mudharabah and Musyarakah Financing Effects on Return On Equity, Journal of Business Administration. Vol. 12, No. 1., 2014

Rahman Aulia Fuad, Rochmanika R. "The influence of buying and selling financing, profit sharing financing, and a non-performing ratio of financing on the profitability of sharia commercial banks in Indonesia, Iqtishoduna Journal, Vol 8, No. 1, 2012.

Rivai, Veithzal, Islamic Banking Islamic Bank System is not only a solution to face a crisis but a solution in the face of various global banking and economic issues. PT. Bumi Aksara: Jakarta, 2010.

Rizky Fadhillah, "The Effect of Implementation of Good Corporate Governance to Financial Performance and Risk of Financing in Islamic Commercial Banks", Proceedings of Industrial Research Workshop and National Seminar 9, 656-660. 2018.

Romdhoni, A. H, "Good Corporate Governance (GCG) in Islamic banking.", Accounting and Tax Journal, Vol 16. No 1., 2015.

Rahayu, YS, Husaini, A., \& Azizah, D. F, "The effect of financing for Mudharabah and Musyarakah results on profitability (study at Islamic General Banks listed on the Indonesia Stock Exchange for the 2011-2014 period". Journal of Business Administration, Vol. 33 No. 1, 2016.

Rivai, veithzal et al, banking and finance (from the work of banks and Islamic finance as solutions and not alternatives). BPFE, First Edition, Yogyakarta, 2012

.Sanjai bhagat. Brian Bolton. "Corporate Governance and Firm Performance". Journal of Corporate Finance ", Volume 14, Number 3, 2008.

Setiawaty Agus. "The Effect of Good Corporate Governance Mechanisms on Banking Performance with Risk Management as Intervening Variables", Economic and Management Journals, Volume 13, No. 1, 2016.

Saramawati, D. A., \& Lubis, A. T. "Analysis of disclosure of the Shariah Compliance in the implementation of Good Corporate Governance Bank Syariah in Indonesia", Journal of Accounting and Islamic Finance, Vol. No. 2, 2014.

Suwiknyo, D. Analysis of Islamic banking financial statements. Student Library, Yogyakarta: 2010. 